\author{
Andrzej Matczak \\ https://orcid.org/0000-0002-9509-5879 \\ University of Łódź \\ Faculty of Geographical Sciences \\ Institute of Urban Geography and Tourism Studies \\ andrzej.matczak@geo.uni.lodz.pl
}

\title{
CHANGES IN THE TOURIST FUNCTION OF KUJAWY HEALTH RESORTS (BASED ON THE CAPACITY AND TYPE OF ACCOMMODATION)
}

\begin{abstract}
The article is an attempt to verify the hypothesis that the tourist function in Polish health resorts is becoming increasingly diversified. It presents data concerning the capacity and type of accommodation in three Kujawy health resorts, as well as their amenities. The data was provided by the Local Data Bank at the Central Statistical Office (GUS), and refers to the period between 1995 and 2018. The study findings point to the increasingly diversification of the tourist function in Kujawy health resorts. The greatest changes have been identified at Ciechocinek which can currently be defined as a tourism and health resort. Less advanced changes have been found in Inowrocław, while Wieniec-Zdrój still remains a typical spa with a marginal share of other functions. Based on official statistics, the author has identified general trends taking place in health resort infrastructure. Only a limited quantitative analysis of the relationship between the health and tourist functions of Kujawy health resorts has been made, mostly due to the incompleteness of the statistical data.
\end{abstract}

Keywords: changes, accommodation structure, Kujawy health resorts, Poland.

\section{INTRODUCTION}

In European countries (e.g. Germany or France) spas are an important element of the settlement network and many have obtained the status of towns. They developed from a specialist health function but when going to spas, patients were usually accompanied by family members or friends who went there not for treatment but for recreation. Thus, from the very beginning, the curative function of spas co-occurred with the recreational function. In Europe, the first spas appeared in antiquity, so many are historical destinations and nowadays, they delight with their urban design, architecture, history, etc., as tourism centres. Spas have always hosted a variety of events, such as concerts or meetings with writers and artists, attracting those who often did not stay overnight, while with their well-developed infrastructure as health resorts organize conferences, meetings, etc. All this indicates that apart from their health function, spas have always had others related to recreation, tourism and entertainment. The popularity of spas among patients and tourists required the development of accommodation and services which provided jobs and good living conditions, attracting newcomers and causing a continuous increase in population. As a result, many health resorts have become tourist centres, although their curative function still determines their spatial organization and socio-economic life.

Before World War II, health resorts in Poland developed in the same way as in the rest of Europe, but that changed after 1945 when spas were nationalized. From then on they provided health services for the 'working people' financed by the state. They were also visited for recreational, tourist or entertainment purposes, but such stays only supplemented the health function. Moreover, spas provided services almost solely for Polish patients. State resources were allocated through large industrial enterprises, workers' unions, ministries and public and economic institutions and building new as well as renovating old facilities resulted in spas having a relatively good infrastructure. This often helped overcome the hardships of the transition period after the reintroduction of a market economy in 1989. Nowadays, spa treatment is still supported by the state (NFZ - National Health Fund, ZUS - Social Insurance Institution, KRUS - Farmers' Social Insurance, PFRON - Disability Rehabilitation Fund), but opening to the market has increased the number of private stays. ${ }^{1}$ Moreover, Polish health resorts have become attractive to foreign patients due to the high standard of service offered 
at relatively low prices compared to similar centres e.g. in Germany (Mika, Ptaszycka-Jackowska, 2007, p. 292; Szczepanowska, 2016; pp. 49-51, and others). All this creates favourable conditions for health resorts in Poland to turn themselves into tourist centres, as is the case in other European countries.

Considering this, it seemed reasonable to test the hypothesis concerning the advancing diversification of the tourist function in Polish health resorts. This was based on a Kujawy spa case study. To achieve this purpose, the author used data and information about the capacity and type of accommodation in Kujawy health resorts, as well as the amenities defining the relationship between health and tourist functions. The author also attempted to evaluate the usefulness of the existing sources of information about accommodation.

\section{LITERATURE REVIEW}

The hypothesis that the development of health resorts leads to their transformation into multifunctional tourism centres is generally positively verified in the literature on the subject (Durydiwka, 2005; Groch, 1991; Jagusiewicz, 1998, 2006; Kowalczyk, 2001, 2005; Krasiński, 2004; Łęcka, 2005; Mika, 2005; Mika, Ptaszycka-Jackowska, 2007; Mościbroda, 2005; PtaszyckaJackowska, 1999; Rzeńca, 1997; Rydz, 2005, 2012; Szromek, 2010, 2012, and others). These were based on observation and descriptive historical analyses but the difficulty in conducting quantitative verification lies in a lack of full and reliable statistics. Kowalczyk (2001, pp. 76-77) presents Bad Homburg (Hesse, Germany) and Mariánské Lázně (Czech Republic) transforming themselves into multifunctional tourism centres with the transformation of Mariánské Lázně into a new accommodation, gastronomic and accompanying infrastructure. Łęcka (2005, p. 42) points to the growing number of cases where the health function of Polish health resorts is supplemented by a recreational tourism function turning them into tourism centres. According to Duridiwka (2005, p. 52), this process depends on the length of the spa treatment tradition at a given destination as well as its popularity, fame and tourist attractiveness. In his analysis of the spa towns in the Low Beskidy and Bieszczady Mountains, Mika (2005, p. 311) indicates that next to sanatorium facilities, a general tourist infrastructure (hotels, guesthouses, private lodgings, etc.) is developing as well, transforming them into tourism centres. The extent of this process is illustrated by the relation between the health and the general tourism infrastructure capacity. Mika, Ptaszycka-Jackowska (2007, pp. 285-286) emphasize that the contemporary socio-economic and cultural changes cause the transformation of traditional spas into multifunctional centres.

Modern health resorts are multifunctional tourism centres (Szromek, 2012, p. 54). Mościbroda (2005, p. 26) claims that the coexistence of a health function and various forms of tourism in spas is a natural phenomenon. In their studies on the process of health resorts transforming into multifunctional tourism centres, many authors refer to Butler's conception (Kowalczyk, 2005, p. 11; Szromek, 2010, pp. 17-40 and others). Academic and popular academic literature on Kujawy spas is relatively large and usually concerns Ciechocinek, Inowrocław and Wieniec-Zdrój.

The bulk of this literature is formed of tourist guides to individual spa towns and their surroundings providing the reader with information about the tourist assets of Kujawy spas and their neighbourhoods which can be used to reconstruct their development (e.g. Umiński, 1978; Winiarski, 2016 and many others).

A presentation of a wider range of issues than those offered in tourist guides can be found in monographs on Inowrocław (e.g. Biskup, 1978; Sikorski, 1988, and others), Ciechocinek (e.g. Iwanowska-Jeske, 1983; Nowakowska, 1953; and others), and WieniecZdrój (Nowakowski, 2015). These publications present the history, location, geographical environment and socio-economic life of the spas (the towns and their immediate surroundings). The description of the socioeconomic aspects of spas makes it possible to define the overall changes which are taking place in their spatial-functional structure.

On the other hand, academic articles written from the perspective of physical and socio-economic geography, as well as sociology, economics, tourism etc., address issues of the assets, infrastructure and touristhealth visits in spa towns. Such works present and explain the origins and development of Kujawy health resorts while scientific-based publications present the unique properties of mineral waters, bioclimate (including graduation towers) - (KozłowskaSzczęsna, 1965; Kucharski, 1973; Ponikowska, Marciniak, 1988; Lecznictwo uzdrowiskowe..., 2011, etc.). Publications presenting socio-economic and spatial issues focus on the recreational assets and curative properties along with prospects for development (Brudnicki, 2005; Głębocki, 2014; Kwiatkowska, 1973), patients' opinions and their perception of spas (Grzeszczak, 2014; Szymańska, Grzelak-Kostulska, Hołowiecka, Michniewicz 2005). They also reconstruct the development process in Ciechocinek and establish its phases (Maik, Przybecka-Maik, 2005), as well as its transformation into a tourism centre (Matczak, 2013). Other authors focus on the place and significance of the spa in the spatial-functional structure of Inowrocław (Maik, Przybecka-Maik, 2014; Matczak, 2013), and on the accommodation in spa towns (Środa-Murawska, 
2012). This body of literature also includes the results of research conducted for MA theses at the university geography departments in Łódź, Bydgoszcz and Torun (Kuzak, 1996; Brzezicka, 2001; Caban, 2017; Cisowski, 2002; Glaza, 2008; Gutsche, 2001; Jędrzejewska, 2002; Kunicki, 2008; Skonieczna, 2011; Świder, 2005; etc.). These publications provide a lot of information based on field research on tourism infrastructure, in particular the scale and structure of the tourist accommodation in Kujawy health resorts. A survey on tourism sponsored by the Kujawy-Pomerania Tourism Organization provides a lot of market information (Anszperger, Radkiewicz, 2011; Brudnicki, Barczak, Nowicki, Markiewicz, 2016) including data about specific accommodation facilities and tourists' reasons for coming to Ciechocinek and Inowrocław.

\section{DATA COLLECTION AND STUDY METHOD}

The author used official statistical data (GUS), supplemented with the results of surveys commissioned by state institutions, conducted on the websites of the Ministry of Health, Ministry of Sport and Recreation, Kujawy-Pomerania Province, and individual health resorts. Published and unpublished academic works (especially MA theses) were an additional source of information.

The Central Statistical Office measures the capacity of tourist accommodation according to their type and number of beds. This measurement is far from perfect due to the imprecise definitions that are used and the incompleteness of information. A spa facility is defined as a one providing health services, located in a health resort and using the natural health resources of the area for treatment. All accommodation at spas is at the tourists' (and patients') disposal. Holiday accommodation facilities (holiday resorts, summer holiday facilities for children and adolescents, training and recreational facilities, creative work centres) also accept guests who have arrived to use the health services of the spa (patients). The same concerns those accommodated at B\&Bs/private lodgings and other unclassified facilities. Those guests often take advantage of outpatient treatment.

It must be remembered however that the data collected, stored and made available by the Central Statistical Office (Local Data Basis and official publications by GUS and the Statistical Office in Bydgoszcz) concern only registered facilities. A significant number of accommodation facilities (especially small ones) remain unregistered which leads to the incompleteness of the data available. This is illustrated by the data for Ciechocinek, presented in Table 1. There are significant discrepancies between the GUS data and the information collected during field research, themselves also incomplete.

Table 1. Accommodation in Ciechocinek in 2010 according to GUS and field research

\begin{tabular}{|c|c|c|c|c|}
\hline \multirow{3}{*}{ Type of accommodation } & \multicolumn{2}{|c|}{$\begin{array}{l}\text { According to } \\
\text { GUS }\end{array}$} & \multicolumn{2}{|c|}{$\begin{array}{l}\text { According to } \\
\text { field research }\end{array}$} \\
\hline & \multicolumn{4}{|c|}{ number } \\
\hline & $\begin{array}{c}\text { facil- } \\
\text { ities }\end{array}$ & beds & \begin{tabular}{|c|} 
facil- \\
ities \\
\end{tabular} & beds \\
\hline $\begin{array}{l}\text { Hotel facilities (hotels, guest- } \\
\text { houses and other hotel-like } \\
\text { facilities) }\end{array}$ & 17 & 922 & 38 & 1266 \\
\hline $\begin{array}{l}\text { Holiday facilities (holiday } \\
\text { resorts, summer holiday facilities } \\
\text { for children and adolescents, } \\
\text { training and recreation centres) }\end{array}$ & 2 & 66 & 12 & 394 \\
\hline $\begin{array}{l}\text { Spa facilities (spas, sanatoria and } \\
\text { spa hospitals) }\end{array}$ & 14 & $2524^{b}$ & 22 & $3909 c$ \\
\hline $\begin{array}{l}\text { Other unclassified facilities } \\
\text { (private lodgings, guest rooms, } \\
\text { agritourist farms, other } \\
\text { accommodation facilities) }\end{array}$ & 1 & 14 & 101 & 1010 \\
\hline Total & 34 & 3526 & 173 & 6579 \\
\hline
\end{tabular}

Key: a according to Skonieczna (2011); b GUS publication, entitled: Lecznictwo uzdrowiskowe w Polsce w latach 2000-2010. [Spa treatment in Poland in 2000-2010] (2011), quotes 3627 beds available; c according to Glaza (2008).

Source: according to GUS and field research.

The incompleteness of the data raises the question whether (and if so for what) analyses based on current statistical data can be made. In the author's opinion, they enable researchers to conduct a fairly precise analysis of current trends concerning capacity, the number of beds, registered facilities (usually large ones such as hotels, spa facilities, holiday and training and recreational centres), followed by smaller-sized facilities like guest rooms, private lodgings, villas, etc. (usually unregistered). Information obtained from sources other than the current GUS reports and used in this article nevertheless play a supplementary and corrective role. The author analysed the collected data, using statistical indices.

\section{TOURIST AND HEALTH (SPA) ASSETS}

Spas in Kujawy are relatively new. In all of them, the curative element has resulted in socio-economic, cultural and spatial development. In Ciechocinek, it led to the establishment of a town (1916), in Inowrocław it significantly boosted an existing town's growth, while in Wieniec-Zdrój it initiated the building and development of a housing estate (1923). 
The health resources of Kujawy spas include saline mineral waters, mild climates, forests, walking areas and therapeutic mud. The waters are used for baths, drinking (after dilution), producing aerosols for natural inhaling, health liquors and mud compresses for the treatment of many chronic diseases (Table 2).

Table 2. Therapeutic types in Kujawy spas: 2010

\begin{tabular}{|l|c|c|c|}
\hline \multicolumn{1}{|c|}{ Therapeutic types } & Ciechocinek & Inowrocław & $\begin{array}{c}\text { Wieniec- } \\
\text { Zdrój }\end{array}$ \\
\hline Orthopaedic trauma & $\mathrm{x}$ & $\mathrm{x}$ & $\mathrm{x}$ \\
\hline Neurological diseases & $\mathrm{x}$ & $\mathrm{x}$ & $\mathrm{x}$ \\
\hline $\begin{array}{l}\text { Rheumatological } \\
\text { diseases }\end{array}$ & $\mathrm{x}$ & $\mathrm{x}$ & $\mathrm{x}$ \\
\hline $\begin{array}{l}\text { Heart diseases } \\
\text { and hypertension }\end{array}$ & $\mathrm{x}$ & $\mathrm{x}$ & \\
\hline $\begin{array}{l}\text { Peripheral vascular } \\
\text { diseases }\end{array}$ & $\mathrm{x}$ & $\mathrm{x}$ & \\
\hline $\begin{array}{l}\text { Upper respiratory } \\
\text { tract diseases }\end{array}$ & $\mathrm{x}$ & & $\mathrm{x}$ \\
\hline $\begin{array}{l}\text { Lower respiratory } \\
\text { tract diseases }\end{array}$ & $\mathrm{x}$ & & $\mathrm{x}$ \\
\hline $\begin{array}{l}\text { Digestive system } \\
\text { diseases }\end{array}$ & $\mathrm{x}$ & \\
\hline Diabetes & & & \\
\hline Obesity & & & \\
\hline Osteoporosis & $\begin{array}{l}\text { Gynaecological } \\
\text { diseases }\end{array}$ & & \\
\hline
\end{tabular}

Source: Lecznictwo uzdrowiskowe... (2011, p. 44).

Nearly two centuries of spa tradition in Ciechocinek, one and a half in Inowrocław and almost 100 years in Wieniec-Zdrój have resulted in the appearance of tourist assets such as urban layouts similar to those observed in parks and decorated with small architectural forms (monuments, statues, fountains, etc.). Spa districts and neighbouring urbanized areas feature historical residential buildings and service facilities (manor houses, villas, etc.), religious buildings and others which make the spa and its urban space more varied. In Ciechocinek, it is worth visiting the local museum which exhibits old devices used for processing salt and rehabilitation. By visiting Inowrocław and Włocławek (as well as the neighbouring Wieniec-Zdrój), you can learn about their cultural heritage going back to the Middle Ages and including historical urban layout and architectural assets. Modern service infrastructure in these towns satisfies (without the additional investments in the spas themselves) the various needs of tourists and patients arriving mainly from large Polish cities. These towns, as well as their spa districts, organize a wide range of events, especially cultural ones, most of which are held between the end of March and the end of September (about three quarters of all annual events).

\section{RESEARCH RESULTS (ORIGINS, DEVELOPMENT AND CHANGES IN THE ACCOMMODATION STRUCTURE)}

Genetically, the settlements performing a health function in Kujawy represent three functional types (cf. Maik, Przybecka-Maik, 2014, p. 15):2

1) a health function was the primary impulse for creating the settlement (Wieniec-Zdrój - 1923),

2) a health function dominated the original productive function (Ciechocinek - 1836),

3) a health function supplemented already welldeveloped productive and service functions (Inowrocław - 1875).

\subsection{KUJAWY HEALTH RESORTS BEFORE THE END OF THE FIRST HALF OF THE $20^{\text {TH }}$ CENTURY}

At an early stage of health resort development in Kujawy, their tourist infrastructure demonstrated the absolute domination of the health function. This was mainly expressed by opening natural treatment facilities, establishing spa parks, building accommodation and gastronomic facilities, as well as places for the patients to spend free time after treatments.

The historical publications familiar to the author do not provide any information about the number of beds at Kujawy spa facilities in the $19^{\text {th }}$ and early $20^{\text {th }}$ centuries. The development rate of the accommodation facilities was indirectly expressed by the fast-growing number of patients, who initially made up over threequarters of their guests, but later dropped to about two-thirds in Ciechocinek and Inowrocław. In WieniecZdrój, which started its spa 'career' in the $20^{\text {th }}$ century, the number of places for patients reached nearly $90 \%$ of the overall accommodation capacity. Similarly, it is difficult to estimate the size of the accommodation infrastructure even after World War II. The figures quoted in GUS statistical records, and in various academic publications and guidebooks, vary. It can be assumed that in the first years after World War II, both the size and structure of the accommodation infrastructure did not differ much from that in the interwar period. The already existing infrastructure, primarily serving the patients, was gradually being rebuilt and restarted.

\subsection{KUJAWY HEALTH RESORTS IN THE PERIOD OF THE CENTRALLY PLANNED ECONOMY}

Basic investments in the accommodation infrastructure of Kujawy health resorts, especially sanatoria, were made during the period of social tourism (Table 3). The first spa facilities appeared in the 1950s in 
Ciechocinek followed by a boom in the 1960s and 1970s, when several large sanatoria and spas were built there and in Inowrocław and Wieniec-Zdrój. Such investments stopped in the 1980s and in the first years following the political and economic transformation after 1989. Money was allocated to the modernization of existing accommodation, spa facilities and the accompanying infrastructure (e.g. modernizing the graduation tower in Ciechocinek, building a new one in Inowrocław, modernizing Wieniec-Zdrój in 200306), as well as renovating parks, promenades, etc. The general aesthetics of spa districts were also improved. In the private sector, investments included renovating and modernizing the spa facilities which had been taken over (e.g. general modernization of the workers' holiday facilities in Ciechocinek), building new hotels, guesthouses, villas, guest rooms and private lodgings. After 1989, the process of privatizing accommodation, former state facilities in particular, or even the whole of Wieniec-Zdrój, was administered by limited liability companies, trade union federations and private owners. It was only after 2000 that a gradual increase in accommodation capacity and changes in its structure could be found. Financial outlays on renovation, modernization and building new facilities were focused, first of all, on year-round facilities, whose proportion was systematically growing almost completely eliminating seasonal facilities.

Table 3. The capacity of new spa treatment facilities in Ciechocinek: 1950-1989

\begin{tabular}{|l|c|c|}
\hline \multicolumn{1}{|c|}{ Years } & No of facilities & No of beds \\
\hline $1951-1960$ & 3 & 470 \\
\hline $1961-1970$ & 7 & 835 \\
\hline $1971-1980$ & 6 & 998 \\
\hline $1981-1989$ & 1 & 70 \\
\hline Total & 17 & 2373 \\
\hline
\end{tabular}

Source: Kuzak (1996).

In the 1970s, apart from the growing number and capacity of spa facilities, an increasing number of accommodation facilities used for the purposes of different forms of tourism, especially recreationa were found. According to GUS records from 1979,3 the tourist accommodation facilities in Ciechocinek offered 2081 beds, 1,561 of which could be found in guest rooms and 2059 in holiday-recreational facilities, including 398 in private lodgings. Thus, the share of guestrooms and private lodgings was substantial. Later GUS records do not include any information about these accommodation facilities, however the earlier records do not contain any data regarding the capacity of spa facilities. Comparing this data with Wysocka's estimates (1989), it can be assumed that spa facilities offered about 3714 beds. In Ciechocinek, the spa function covered $47.3 \%$ of the accommodation capacity, while according to Wysocka the health-spa facilities included $41 \%$ of accommodation and recreationaltourist ones, $59 \%$. A larger proportion of accommodation facilities for tourists were also found in Inowrocław, but it was definitely less than for spa facilities. In Wieniec-Zdrój these clearly dominated accommodation with respect to number and capacity. The development of accommodation for tourists in Kujawy health resorts seems to be related to the duration of their activity as health destinations.

\subsection{KUJAWY HEALTH RESORTS AFTER THE RETURN TO A MARKET ECONOMY}

After a short period of temporary difficulties, returning to a market economy after 1989 resulted in a dynamic increase in the scale of tourist accommodation in Kujawy health resorts. Ciechocinek, Inowrocław and Wieniec-Zdrój have always been important health centres and by the mid-1990s, they offered nearly 2000 beds at spa facilities, which made up about 5.6\% of all such places in Poland. Towards the end of the second decade of the 21 $1^{\text {st }}$ century, the number of beds at spa hospitals, sanatoria, spa clinics and natural medicine facilities had increased to 7,200 , which was $16.1 \%$ of national resources.

The three spa towns in Kujawy have been systematically increasing tourist accommodation in KujawyPomerania Province (Table 4). In 1995, they offered 2,600 beds at registered tourist facilities, which was $9.3 \%$ of the number for the whole province, while in 2018 they offered 9,200 beds, which made up $28.4 \%$ of accommodation in Kujawy-Pomerania Province and over one third of its year-round overnight accommodation.

The rate of increase as regards places at registered accommodation in Kujawy health resorts in 1995-2018, was three times higher than in the whole province. The capacity of spa facilities was growing slightly faster (over 3.5 times) than that of the remaining accommodation (3 times).

Based on official statistical data, two main trends can be identified in the development of tourist accommodation in Kujawy health resorts. The first concerns its type. Many hotel-like facilities which were popular at the time of centrally planned economy, such as excursion centres, etc, were closed down in the 1990s. The official statistics included a group referred to as 'other hotel facilities' whose share of recreational facilities (resort hotels, summer holiday centres for children, training and recreation facilities, artists' retreats) clearly decreased (marginally in Ciechocinek). The predominant position was still held by spa facilities which offered a steadily increasing number of beds. 
Tourism 2019, 29/1

Table 4. The number of registered accommodation facilities and places/beds in Kujawy-Pomerania Province and its three spas: 1995-2018

\begin{tabular}{|c|c|c|c|c|c|c|c|c|c|c|}
\hline \multirow{2}{*}{ Year } & \multicolumn{2}{|c|}{$\begin{array}{c}\text { Kujawy-Pomerania } \\
\text { Province }\end{array}$} & \multicolumn{2}{|c|}{$\begin{array}{c}\text { Kujawy health resorts, } \\
\text { jointly }\end{array}$} & \multicolumn{2}{|c|}{ Ciechocinek } & \multicolumn{2}{|c|}{ Inowrocław } & \multicolumn{2}{|c|}{ Wieniec-Zdrój } \\
\hline & facilities & places & facilities & places & facilities & places & facilities & places & facilities & places \\
\hline \multicolumn{11}{|c|}{ Tourist accommodation facilities - total } \\
\hline 1995 & 388 & 28027 & 21 & 2601 & 9 & 758 & 10 & 1637 & 2 & 206 \\
\hline 2000 & 431 & 29980 & 31 & 3910 & 18 & 1741 & 11 & 1766 & 2 & 403 \\
\hline 2005 & 338 & 26325 & 32 & 4442 & 22 & 2271 & 8 & 1861 & 2 & 310 \\
\hline 2010 & 316 & 24843 & 45 & 5791 & 34 & 3526 & 8 & 1875 & 3 & 390 \\
\hline 2015 & 367 & 28515 & 67 & 7569 & 48 & 5372 & 14 & 1897 & 5 & 300 \\
\hline 2018 & 414 & 32259 & 75 & 9175 & 57 & 5866 & 15 & 2113 & 3 & 1196 \\
\hline \multicolumn{11}{|c|}{ Spa facilities } \\
\hline $1995^{\mathrm{a}}$ & 8 & 1942 & 8 & 1942 & 3 & 433 & 4 & 1336 & 1 & 173 \\
\hline 2000 & 15 & 3334 & 15 & 3334 & 9 & 1472 & 5 & 1480 & 1 & 382 \\
\hline 2005 & 14 & 3492 & 14 & 3492 & 8 & 1488 & 5 & 1702 & 1 & 302 \\
\hline 2010 & 20 & 4576 & 20 & 4576 & 14 & 2524 & 5 & 1707 & 1 & 345 \\
\hline 2015 & 33 & 6053 & 33 & 6053 & 22 & 4100 & 8 & 1688 & 3 & 265 \\
\hline 2018 & 30 & 7157 & 30 & 7157 & 21 & 4203 & 8 & 1810 & 1 & 1144 \\
\hline \multicolumn{11}{|c|}{ Tourist and holiday facilities } \\
\hline 1995 & 380 & 26085 & 13 & 659 & 6 & 325 & 6 & 301 & 1 & 33 \\
\hline 2000 & 416 & 26646 & 16 & 576 & 9 & 269 & 6 & 286 & 1 & 21 \\
\hline 2005 & 324 & 22833 & 18 & 950 & 14 & 783 & 3 & 159 & 1 & 8 \\
\hline 2010 & 296 & 20267 & 25 & 1215 & 20 & 1002 & 3 & 168 & 2 & 45 \\
\hline 2015 & 331 & 22462 & 34 & 1516 & 26 & 1272 & 6 & 209 & 2 & 35 \\
\hline 2018 & 384 & 25102 & 45 & 2018 & 36 & 1663 & 7 & 303 & 2 & 52 \\
\hline
\end{tabular}

a Data for 1998.

Source: based on the Local Data Bank, Central Statistical Office (GUS).

In the period of 2000-18, the mean annual increase in the number of beds in Ciechocinek was $11.3 \%$, in Wieniec-Zdrój - 9.4\%, and in Inowrocław - 1.1\%, and was several times higher than the increase in the remaining accommodation facilities (including categorized hotels). It seems that in the near future, higher outlays on hotels in Kujawy health resorts can be expected with large investors are becoming increasingly interested in building hotels not only in large cities, but also in smaller towns and in areas of high tourist value, such as the Kujawy spas.

In 2000, Ciechocinek and Inowrocław had similar capacities of registered accommodation $(44.5 \%$ and $45.2 \%$, respectively) both as regards tourist-recreational and spa facilities, while Wieniec-Zdrój had only one tenth of what the other two spa towns had to offer. In 2015, Ciechocinek's share had increased to 71\%, Inowrocław decreased to $25 \%$, and Wieniec-Zdrój to $4 \%$. By 2018, new investments had led to the following changes: in Wieniec-Zdrój - an increase to $13.1 \%$, in Ciechocinek - a decrease to $63.9 \%$, and in Inowrocław - to $23 \%$. One result of the varying growth rates has been Ciechocinek's stable leading position.

In the period of 2000-2018, the share of spa facilities in the total capacity of registered accommodation was steadily falling from $85.3 \%$ in 2000 to $78 \%$ in 2018 , but the decrease was only found in Ciechocinek where the share dropped from $84.5 \%$ to $71.6 \%$. In Inowrocław and Wieniec-Zdrój, there was a slight increase (from $83.8 \%$ to $85.7 \%$ and from $94.8 \%$ to $95.6 \%$, respectively).

The growing diversification of the tourist function structure in Kujawy health resorts is also illustrated by sports and recreational amenities intended for disabled people, as well as conference halls and restaurants (Table 5). The common use and variety of these amenities point to the Kujawy resorts being prepared to provide services in forms of tourism other than health. In this respect, the most wide-ranging services are offered by Ciechocinek.

The gastronomic infrastructure consisted of food establishments situated in the sanatoria, spa parks and nearby, as well as in other parts. The establishments that were most important for patients were those situated in sanatoria, such as dining rooms. All large sanatoria had their own kitchens. It is estimated that in the summer season, the gastronomic facilities in Ciechocinek offered over 7100 places, in the spa zone of Inowrocław - about 1000 places, but fewer in Wieniec-Zdrój. The gastronomic facilities varied and were prepared to satisfy the different culinary needs of the guests. Gastronomic establishments, such as restaurants, cafes and some dining rooms, were also prepared to organize dance evenings, ice-breaking parties and other similar events. 
Table 5. Sports and recreational amenities, conference and gastronomic facilities, as well as amenities for the disabled at Kujawy spa accommodation: 2017-2018

\begin{tabular}{|c|c|c|c|c|}
\hline Facilities with amenities & Ciechocinek & Inowrocław & Wieniec-Zdrój & Total \\
\hline \multicolumn{5}{|l|}{ 1) sports-recreational: } \\
\hline - volleyball or basketball court & 3 & 1 & - & 4 \\
\hline - tennis court & 3 & - & - & 3 \\
\hline - indoor swimming pool & 14 & 2 & 1 & 17 \\
\hline - outdoor swimming pool & 1 & - & - & 1 \\
\hline - gym & 18 & 5 & 1 & 24 \\
\hline - sauna & 17 & 4 & 1 & 22 \\
\hline - solarium & 2 & - & - & 2 \\
\hline - SPA treatments & 14 & 3 & 1 & 18 \\
\hline - rehabilitation treatments (massages, physiotherapy, etc.) & 27 & 8 & 1 & 36 \\
\hline $\begin{array}{l}\text { - classes conducted by an instructor (e.g. fitness, yoga, aerobics, } \\
\text { exercise) }\end{array}$ & 20 & 6 & 1 & 27 \\
\hline - billiards & 6 & 2 & 1 & 9 \\
\hline - table tennis equipment & 11 & 1 & 1 & 13 \\
\hline $\begin{array}{l}\text { - tourist equipment rental (e.g. bicycles, } \\
\text { Nordic walking sticks, roller-skates, etc.) }\end{array}$ & 24 & 3 & 1 & 28 \\
\hline - bowling & - & - & 1 & 1 \\
\hline - playrooms for children & 6 & 1 & 1 & 8 \\
\hline \multicolumn{5}{|l|}{ 2) for people with motor disability: } \\
\hline - ramps & 26 & 7 & 1 & 34 \\
\hline - automatic doors & 17 & 3 & 1 & 21 \\
\hline - lifts & 26 & 9 & 1 & 36 \\
\hline - car park with places reserved & 20 & 8 & 1 & 29 \\
\hline \multicolumn{5}{|l|}{ 3) conference: } \\
\hline - with a conference hall & 19 & 8 & 1 & 28 \\
\hline - number of conference halls & 43 & 10 & 5 & 58 \\
\hline - number of seats in the conference hall & 3223 & 646 & 700 & 4569 \\
\hline - with a sound system & 15 & 10 & 1 & 26 \\
\hline - with a cordless microphone & 12 & 9 & 1 & 22 \\
\hline - with a multimedia projector & 20 & 7 & 1 & 28 \\
\hline - with a videoconference set & 5 & - & 1 & 6 \\
\hline - with technical service & 14 & 4 & 1 & 19 \\
\hline - with a screen & 20 & 8 & 1 & 29 \\
\hline - with a flipchart (whiteboard) & 19 & 8 & 1 & 28 \\
\hline - with a computer or laptop & 17 & 2 & 1 & 20 \\
\hline - with WiFi at the facility & 35 & 10 & 2 & 47 \\
\hline \multicolumn{5}{|l|}{ 4) gastronomic establishments: } \\
\hline - restaurants & 16 & 5 & 1 & 22 \\
\hline - bars and cafes & 11 & - & 3 & 14 \\
\hline - dining rooms & 18 & 7 & 1 & 26 \\
\hline - food outlets/points & 2 & - & - & 2 \\
\hline
\end{tabular}

Source: based on the Local Data Bank (GUS).

Kujawy health resorts have a well-developed supplementary infrastructure available at spa and tourist facilities which consists of various amenities supporting treatment and recreation: graduation towers, indoor saline baths, tennis courts, mini-golf, bowling alleys, common room games, billiards, table tennis, library classes, etc. In Ciechocinek and Inowrocław, the inhabitants as well as the patients and tourists may use the stadium, sports hall, a sports and recreation centre, bike rental, tourist trips to Lichen, Torun, Kruszwica, Biskupin, Żnin and other destinations; a cinema, an open-air theatre, an open-air stage and a very wide range of services. Motorized tourists have several car parks at their disposal. Based on the supplementary infrastructure, it is possible to enjoy a number of events, such as parties, dance evenings, festivals and concert evenings, Kujawy and Dobrzyń folklore events etc. Some sanatoria offer additional SPA treatments in the solarium, beauty parlour, sauna and the common room; a Tibetan massage with hot stones, inhalations in a salt grotto, etc. They also organize lectures promoting a healthy lifestyle, conducted by qualified psychologists and doctors, sharing their knowledge about the causes of civilization dis- 
eases. Spa facilities featured 58 conference halls with 4500 seats equipped with modern audio-visual equipment (sound system, microphones, image projectors, screens, computers, etc.). The largest conference halls can be found at spa facilities in Ciechocinek, followed by Inowrocław and Wieniec-Zdrój.

\section{DISCUSSION}

So far, official statistics have not provided information about the actual number of beds available in guest rooms/private lodgings, villas, small hotels, etc. It is this particular type of accommodation that is significant as regards tourists and out-patients. Official statistical data from the late 1970s reported the accommodation capacity in Ciechocinek at nearly 2000 beds. In the years to follow, many owners in Ciechocinek stopped declaring services (staying outside statistical registration), but this kind of accommodation did not disappear. Currently, Ciechocinek is inhabited by about 10,000 people, living in 20,900 rooms. There are, on average, two rooms $\left(30 \mathrm{~m}^{2}\right)$ per resident with the surplus rooms, at least partly, being let to tourists and patients. This has been confirmed by the Spokesperson of the Kujawy-Pomerania Province Marshal, quoting a figure of 12,000 beds in Ciechocinek. The size of unregistered accommodation in Inowrocław seems to be smaller. However, on the town's websites, it is possible to identify several (over 20) villas, pensions, apartments, residences, whose names include words like hotel, guest rooms, inn, or even recreational centre. Yet, they are not included in official GUS statistics. At present, Inowrocław is inhabited by 73,600 people living in 104,200 rooms. On average, there are 1.4 rooms $\left(13.2 \mathrm{~m}^{2}\right)$ per inhabitant, which also points to the existence of surplus rooms for rent. Since 2000, housing resources in Ciechocinek have increased by $27.2 \%$ (5700 rooms), and in Inowrocław by about $15.8 \%$ $(16,400$ rooms) while, at the same time, the number of inhabitants has decreased: in Ciechocinek by $6.7 \%$ (ca. 1000) and in Inowrocław by $7.3 \%$ (ca. 6200). This points to a considerable interest of the inhabitants of both towns in increasing housing resources to improve their living conditions, but also in providing them with significant income from renting rooms to tourists and patients. In Wieniec-Zdrój, this type of unregistered accommodation infrastructure is far less important. Newly built housing can be found outside the spa, in Wieniec solectwo where the investors are also inhabitants of Włocławek.

The direction of change taking place in accommodation capacity in Kujawy heath resorts is confirmed by the figures for the tourist function coefficient (according to Baretje \& Defert ${ }^{4}$ ) presented in Table 6. They show that in the period 2000-18, in Kujawy health resorts, the figures for the spa and the touristrecreational function coefficients increased. WieniecZdrój had and still has a well-developed spa function, with a relatively weak tourist-recreational function. This was determined by the large capacity of the registered accommodation infrastructure and, at the same time, a small number of residents (128). The weakest spa as well as tourist and recreational functions was in Inowrocław, due to its relatively small accommodation capacity and a large number of residents. It is a characteristic feature of larger cities, where despite the great economic significance of tourism, the function is weak in terms of the coefficient used $\left(W_{B D}\right)$. In 2000, according to this coefficient calculated on the basis of registered accommodation capacity, Ciechocinek had poorly developed tourist and recreational functions, but in 2018, it could be named as a Polish tourist town $\left(W_{B D}>50\right)$ due to the capacity of spa facilities. On the other hand, taking the capacity of unregistered accommodation facilities into account, Ciechocinek was a town with a fully developed tourist function $\left(W_{B D}>100\right)$ with a larger capacity of tourist-recreational than spa facilities $\left(W_{B D}=78\right.$ and $W_{B D}=42,1$, respectively).

Table 6. Figures for the tourist function coefficient (according to Baretje \& Defer) $\left(W_{B D}\right)$

\begin{tabular}{|l|c|c|c|c|c|c|}
\hline \multirow{2}{*}{ Specification } & \multicolumn{2}{|c|}{ Ciechocinek } & \multicolumn{2}{c|}{ Inowrocław } & \multicolumn{2}{c|}{$\begin{array}{c}\text { Wieniec- } \\
\text { Zdrój }\end{array}$} \\
\cline { 2 - 7 } & 2000 & 2018 & 2000 & 2018 & 2000 & 2018 \\
\hline $\begin{array}{l}\text { Total of tourist } \\
\text { accommodation } \\
\text { facilities }\end{array}$ & 15.8 & 58.7 & 2.2 & 2.9 & 314.8 & 934.4 \\
\hline $\begin{array}{l}\text { Spa facilities, } \\
\text { exclusively }\end{array}$ & 13.4 & 42.1 & 1.8 & 2.5 & 298.4 & 893.7 \\
\hline $\begin{array}{l}\text { Tourist-recreational } \\
\text { facilities, exclusively }\end{array}$ & 2.4 & 16.6 & 0.4 & 0.4 & 16.4 & 40.7 \\
\hline
\end{tabular}

Source: author's calculations based on official statistics on accommodation.

The data from official statistics allow us to identify general trends in the tourist function in Kujawy health resorts. However, providing more detail requires field inventory research (which also has its limitations) as well as searching for or testing alternative indices identifying ongoing changes, regarding both supply (e.g. available housing resources) and demand (e.g. the types and motivations of spa visitors).

\section{CONCLUSIONS}

Kujawy health resorts offer a wide variety of accommodation, catering, entertainment and treatment for patients and tourists. However, estimating the actual capacity and structure of accommodation still remains 
a difficult task. The usefulness of official statistics in identifying the functions of spas other than health is limited. Attempts to supplement them with other sources of information, such as on-line questionnaires regarding a variety of institutions and tourist facilities, as well as some field research (the author's own inventory), do not provide full knowledge of the scale and type of tourist accommodation in the health resorts included in the study.

Nevertheless, the tourist infrastructure in Kujawy health resorts confirms a regularity observed in resorts all over the world: health functions are supplemented with other forms of tourism involving active recreation (using amenities such as graduation towers, swimming pools, tennis courts, sports fields, etc.), during long and short (weekend) stays. Other activities include sightseeing, entertainment and attending conferences. Nowadays, the infrastructure at Ciechocinek tourist facilities is at least as large as at spa facilities, which points to a considerable diversification of the tourism sector there. These changes are less visible in Inowrocław, and in Wieniec-Zdrój they are still to come.

\section{ENDNOTES}

1 In 2017, the share of private patients in Polish health resorts was $34.7 \%$ (health activity at spa treatment facilities and rehabilitation centres in 2017. The Statistical Office in Kraków, Health and Health Protection Statistics Centre).

${ }^{2}$ Maik \& Przybecka-Maik (2014) report that with regard to the causative role of urban functions, spa towns can be divided into three groups: 1) those where health functions were the primary impulse triggering town development (e.g. Krynica); 2) those where the original manufacturing or service function was being gradually dominated by the health function (e.g. Ciechocinek); 3) those where developed urban functions were at some stage supplemented with health functions (e.g. Inowrocław, Sopot).

${ }^{3}$ Turystyka $i$ wypoczynek $w 1979 r$. [Tourism and recreation in 1979], (1980).

${ }^{4}$ It was calculated using the $W_{B D}=\frac{L_{M N}}{L_{M}} \cdot 100$ formula, where $W_{B D}$ - tourist function index, $L_{M N}$ - number of beds at accommodation facilities, $L_{M}$ - number of inhabitants.

\section{BIBLIOGRAPHY}

Anszperger, A., Radkiewicz, A. (2011). Badania ruchu turystycznego w województwie kujawsko-pomorskim w latach 2009-2010. Vol. 2. Torun: Wyd. Kujawsko-Pomorska Organizacja Turystyczna.

Biskup, M. (ed.). (1978). Dzieje Inowrocławia. Inowrocław: Państwowe Wydawnictwo Naukowe.

Brudnicki, R. (2005). Uzdrowisko Inowrocław - stan aktualny i możliwości dalszego rozwoju. In: E. Rydz (ed.), Ksztattowanie funkcji turystycznych w miejscowościach uzdrowiskowych (pp. 318-325). Słupsk: Wydawnictwo Pomorskiej Akademii Pedagogicznej.

Brudnicki, R., Barczak, M., Nowicki, R., Markiewicz, P. (2016). Monitoring ruchu turystycznego w województwie kujawskopomorskim - 2015. Raporty z rejonów badań wykonanych dla Kujawsko-Pomorskiej Organizacji Turystycznej. Bydgoszcz: Wyższa Szkoła Gospodarcza.

Brzezicka, A. (2001). Funkcja turystyczna i wypoczynkowo-sanatoryjna miasta Inowrocławia. Toruń: Uniwersytet Mikołaja Kopernika. MA thesis, promoter: D. Szymańska.

Caban, M. (2017). Ruch turystyczny w uzdrowisku Wieniec-Zdrój. Łódź: Uniwersytet Łódzki, Wydział Nauk Geograficznych. MA thesis, promoter: A. Matczak.

Cisowski, M. (2002). Ruch sanatoryjny w uzdrowisku Inowroctaw. Łódź: Uniwersytet Łódzki, Wydział Nauk Geograficznych. MA thesis, promoter: A. Matczak.

Durydiwka, M. (2005). Zróżnicowanie rozwoju funkcji turystyczno-rekreacyjnych w miejscowościach uzdrowiskowych In: E. Rydz (ed.), Kształtowanie funkcji turystycznych w miejscowościach uzdrowiskowych (pp. 46-59). Słupsk: Wydawnictwo Pomorskiej Akademii Pedagogicznej.

Działalność lecznicza zakładów lecznictwa uzdrowiskowego i stacjonarnych zakładów rehabilitacji leczniczej w 2017 r. Informacje sygnalne (2017). Kraków: US w Krakowie, Ośrodek Statystyki Zdrowia i Ochrony Zdrowia.

Glaza, M. (2008). Zachowania przestrzenne kuracjuszy i turystów $w$ Ciechocinku. Bydgoszcz: Uniwersytet Kazimierza Wielkiego, MA thesis, promoter: A. Matczak

Głębocki, B. (2014). Walory rekreacyjno-uzdrowiskowe Inowrocławia i ich wpływ na rozwój miasta. Zeszyty Naukowe Wyższej Szkoty Gospodarczej, 23, ser.: Turystyka i Rekreacja, 11, 119-141.

Groch, J. (1991). Badania diagnostyczne uzdrowisk polskich $z$ zastosowaniem wieloczynnikowej analizy porównawczej. Kraków: Uniwersytet Jagielloński.

Grzeszczak, S. (2014). Turystyka w Inowrocławiu w opinii kuracjuszy. Zeszyty Naukowe Wyższa Szkoła Gospodarcza, 23, ser. Turystyka i Rekreacja, 11, 143-149.

Gutsche A. (2001). Postrzeganie miasta Ciechocinek przez kuracjuszy. Torun: Uniwersytet Mikołaja Kopernika. MA thesis, promoter: D. Szymańska.

Iwanowska-Jeske, D. (1983). Uzdrowisko Ciechocinek. Zarys monograficzny. Warszawa: Sport i Turystyka.

Jagusiewicz, A. (1998). Problemy lecznictwa i turystyki w uzdrowiskach polskich. Warszawa: Instytut Turystyki.

Jagusiewicz, A. (2006). Turystyka Uzdrowiskowa. Warszawa: Instytut Turystyki.

Jędrzejewska, A. (2002). Zmiana funkcji turystycznej Ciechocinka w latach 90. XX wieku. Łódź: Uniwersytet Łódzki, Wydział Nauk Geograficznych. MA thesis, promoter: S. Liszewski.

Kowalczyk, A. (2001). Geografia turyzmu. Warszawa: Wydawnictwo Naukowe PWN.

Kowalczyk, A. (2005). Transformacja uzdrowiska w wielofunkcyjny ośrodek turystyczny - przykład Mariańskich Łaźni (Czechy). In: E. Rydz (ed.), Kształtowanie funkcji turystycznych w miejscowościach uzdrowiskowych (pp. 11-21). Słupsk: Wydawnictwo Pomorskiej Akademii Pedagogicznej.

Kozłowska-Szczęsna, T. (1965). Bioklimat Ciechocinka. Problemy Uzdrowiskowe, $4 / 26$

Krasiński, Z. (2004). Cykle życia uzdrowisk: od narodzin po... . Kołobrzeg: Agencja Wydawnicza „Patan-Press”.

Kucharski, M. (1973). Warunki fizjograficzne doliny Wisły pod Ciechocinkiem (w aspekcie turystyki i wypoczynku). Prace Wydziału Nauk Humanistycznych, ser. G. Bydgoszcz.

Kwiatkowska, E. (1973). Miasta. In: A. Świniarski (ed.), Województwo bydgoskie (pp. 239-263). Poznań: PWN. 
Kunicki, M. (2008). Rola funkcji uzdrowiskowej w życiu społecznoekonomicznym Inowroctawia. Bydgoszcz: Uniwersytet Kazimierza Wielkiego. MA thesis, promoter: A. Matczak.

Kuzak, A. (1996). Funkcja turystyczna Ciechocinka. Łódź: Uniwersytet Łódzki, Wydział Nauk Geograficznych. MA thesis, promoter: S. Liszewski.

Lecznictwo uzdrowiskowe w Polsce w latach 2000-2010. (2011). Kraków: GUS.

Madeyski, A. (1997). Polskie uzdrowiska, ich charakterystyka i główne problemy. Problemy Turystyki, 1-4, (XX), 91-105.

Maik, W., Przybecka-Maik, M. (2005). Rozwój i przemiany funkcjonalno-przestrzenne Ciechocinka pod wpływem funkcji turystyczno-uzdrowiskowych. In: E. Rydz (ed.), Kształtowanie funkcji turystycznych $w$ miejscowościach uzdrowiskowych (pp. 239-250). Słupsk: Wydawnictwo Pomorskiej Akademii Pedagogicznej.

Maik, W., Przybecka-Maik, M. (2014). Miasta-uzdrowiska jako ważny element sieci miejskiej Europy - ich specyfika i mechanizm rozwojowy. Zeszyty Naukowe Wyższej Szkoty Gospodarczej, 23, ser.: Turystyka i Rekreacja, 11, 9-31.

Matczak, A. (2012). Funkcja uzdrowiskowa w przestrzeni Inowrocławia. In: E. Rydz (ed.), Ekonomiczne i organizacyjne aspekty funkcjonowania polskich uzdrowisk (pp. 167-181). Słupsk: Wydawnictwo Naukowe Akademii Pomorskiej.

Matczak, A. (2013). Proces przekształcania uzdrowiska w ośrodek turystyczny. Przykład Ciechocinka. In: S. Sitek (ed.), "Stare $i$ nowe" problemy badawcze w geografii spotecznoekonomicznej. Vol. 5 (pp. 97-115). Sosnowiec.

Mika, M. (2005). Możliwości rozwoju uzdrowisk Beskidu Niskiego i Bieszczad w świetle obecnych uwarunkowań. In: E. Rydz (ed.), Ksztattowanie funkcji turystycznych w miejscowościach uzdrowiskowych (pp. 308-317). Słupsk: Wydawnictwo Pomorskiej Akademii Pedagogicznej.

Mika, M., Ptaszycka-Jackowska, D. (2007). Formy turystyki zdrowotnej. In: W. Kurek (ed.), Turystyka (pp. 279-291). Warszawa: Wydawnictwo Naukowe PWN.

Mościbroda, J. (2005). Rozwój funkcji turystycznych i rekreacyjnych w uzdrowisku Nałęczów. In: E. Rydz (ed.), Kształtowanie funkcji turystycznych w miejscowościach uzdrowiskowych (pp. 22-29). Słupsk: Wydawnictwo Pomorskiej Akademii Pedagogicznej.

Nowakowska, L. (1957). Ciechocinek. Prace Geograficzne, 9, 285-300.

Nowakowski, W. (2015), Historia uzdrowiska Wieniec 1907-1997 piórem Naczelnego Lekarza. Włocławek: EXPOL.

Ponikowska, J., Marciniak, K. (1988). Ciechocinek. Terenoterapia uzdrowiskowa. Warszawa-Poznań: PWN.

Ptaszycka-Jackowska, D. (1999). Lecznictwo uzdrowiskowe a turystyka. Turyzm, 9 (1), 201-208.
Rydz, E. (ed.). (2005). Ksztattowanie funkcji turystycznych w miejscowościach uzdrowiskowych. Słupsk: Wydawnictwo Pomorskiej Akademii Pedagogicznej.

Rydz, E. (ed.). (2012). Ekonomiczne i organizacyjne aspekty funkcjonowania polskich uzdrowisk. Słupsk: Wydawnictwo Naukowe Akademii Pomorskiej.

Rzeńca, P. (1997). Iwonicz Zdrój - przykład koegzystencji funkcji uzdrowiskowej i wypoczynkowej z innymi funkcjami miasta. Turyzm, 7 (1), 73-95.

Sikorski, C. (1988). Miasto na soli - zarys historii Inowroctawia do roku 1919. Warszawa: Wydawnictwo Spółdzielcze.

Skonieczna, E. (2011). Funkcja turystyczna Ciechocinka. Bydgoszcz: Wyższa Szkoła Gospodarcza. MA thesis, promoter: A. Matczak.

Szczepanowska, E. (2016). Uzdrowisko jako miejscowość turystyczna. In: G. Koźmiński (ed.), Turystyka zdrowotna, uzdrowiskowa i uwarunkowania bioklimatyczne (pp. 49-51). Szczecin: Wydawnictwo Naukowe Uniwersytetu Szczecińskiego.

Szromek, A.R. (2010). Cykliczność rozwoju uzdrowisk na przykładzie uzdrowisk polskich. In: A.R. Szromek (ed.), Uzdrowiska $i$ ich znaczenie $w$ gospodarce turystycznej (pp. 17-40). Kraków: Wyd. Proksenia.

Szromek, A.R. (2012). Funkcja uzdrowiskowa i jej znaczenie w gospodarce gmin uzdrowiskowych. In: A.R. Szromek (ed.), Uzdrowiska i ich funkcja turystyczno-lecznicza (pp. 35-58). Kraków: Wyd. Proksenia.

Szymańska, D., Grzelak-Kostulska E., Hołowiecka B., Michniewicz H. (2005). Postrzeganie miejscowości turystycznouzdrowiskowych na przykładzie Ciechocinka i Inowrocławia. In: E. Rydz (ed.), Kształtowanie funkcji turystycznych w miejscowościach uzdrowiskowych (pp. 293-307). Słupsk: Wydawnictwo Pomorskiej Akademii Pedagogicznej.

Środa-Murawska, S. (2012). Miasta uzdrowiskowe w Polsce w ujęciu wielkości i struktury bazy obiektów zbiorowego zakwaterowania. In: E. Rydz (ed.), Ekonomiczne i organizacyjne aspekty funkcjonowania polskich uzdrowisk (pp. 21-29). Słupsk: Wydawnictwo Naukowe Akademii Pomorskiej.

Świder, I. (2005). Hotel Villa Park w Ciechocinku jako przedstawiciel grupy markowej Polish Prestige Hotel and Resorts. Łódź: Uniwersytet Łódzki, Wydział Nauk Geograficznych. MA thesis, promoter: B. Włodarczyk.

Turystyka i wypoczynek w 1979 r. (1980). Warszawa: GUS.

Umiński, J. (1978). Ciechocinek i okolice. Warszawa: Sport i Turystyka.

Winiarski, A. (2016). Wieniec-Zdrój i okolice. Przewodnik. Włocławek: Oficyna Wydawnicza „Lars-Antyki”.

Wysocka, E. (1989). Rola pasm uzdrowiskowo-wypoczynkowych. Warszawa: Instytut Turystyki.

Article received:

1 March 2019

Accepted:

25 April 2019 